\title{
APPLICATION OF DIFFERENT SEISMIC ANALYSES TO RC STRUCTURES
}

\author{
Scientific paper / Znanstveni rad \\ Nikolina Karakaš \\ OSIJEK-KOTEKS d.d., VELIČKI KAMEN d.o.o., PhD Student \\ Corresponding author: nikolina.karakas@gmail.com \\ Tanja Kalman Šipoš \\ University of Osijek, Faculty of Civil Engineering and Architecture Osijek, Assistant professor \\ Marijana Hadzima-Nyarko \\ University of Osijek, Faculty of Civil Engineering and Architecture Osijek, Assistant professor

\begin{abstract}
Static and dynamic methods of nonlinear seismic analysis for reinforced concrete non-seismic buildings are presented in this paper. The ICONS experimental model was used on a reinforced concrete four-story frame with three bays, which was calibrated with a numerical nonlinear model. The chosen earthquake record was a moderate-strong scenario of the European Seismic Hazard. The numerical model showed excellent correlation with the experimental behavior of the ICONS model. The methods that were used in this study are as follows: pushover analysis, time history analysis, and incremental dynamic analysis. The advantages and disadvantages of each method are described, and the results obtained by their application are presented. The pushover analysis shows the expected global response of the structure, which is confirmed by the numerical results and recommendations for performance levels. The results obtained from the time history analysis are interstory drift profiles based on three different peak ground accelerations. Finally, the incremental dynamic analysis shows fragility curves based on the first natural period of the structure.
\end{abstract}

Keywords: nonlinear seismic analysis; reinforced concrete frame; interstory dritt ratio; fragility curve; capacity curve

\section{PRIMJENA RAZLIČITIH SEIZMIČKIH ANALIZA NA AB KONSTRUKCIJAMA}

Sažetak: U radu su prikazane nelinearne statčke i dinamičke seizmičke analize na armiranobetonskoj, neseizmički projektiranoj konstrukciji. Korišten je eksperimentalni model ICONS, armiranobetonski četverokatni okvir s tri raspona, koji je kalibriran s numeričkim nelinearnim modelom. Odabrani zapis potresa je jedan od umjereno jakih scenarija europske seizmičke opasnosti. Numerički je model pokazao odličnu korelaciju u odnosu na rezultate eksperimentalnog ispitivanja ICONS modela. Provedene i ispitane metode su metoda postupnog guranja, analiza vremenskog zapisa potresa i inkrementalna dinamička analiza. Prednosti i nedostatci svake od metoda su opisani, a njihovi rezultati prikazani. Metoda postupnog guranja pokazuje očekivani globalni odgovor konstrukcije, što je potvrđeno numeričkim rezultatima i preporukama za područja ponašanja. Rezultati analize vremenskog zapisa potresa su međukatni pomaci zasnovani na tri različite vrijednosti vršnih ubrzanju tla, dok inkrementalna dinamička analiza prikazuje krivulje oštetjijosti na osnovi prvog prirodnog perioda konstrukcije.

Ključne riječi: nelinearna seizmička analiza; armiranobetonski okvir; međukatni pomak; krivulja oštetjjivosti; krivulja kapaciteta 


\section{INTRODUCTION}

Earthquakes can cause structural damage, which negatively reflects on humans in every way. The consequences of an earthquake can be disastrous with regard to economic losses, human suffering, and even the loss of human life. These consequences are directly connected to the magnitude of the earthquake.

There are numerous structures that were not designed according to seismic provisions that take into account the performance of structures owing to seismic loading. The methods that are used in this study are as follows: pushover analysis (PA), time history analysis (THA), and incremental dynamic analysis (IDA). The aim of these methods is to obtain the response of the structure under possible earthquake scenarios. The interconnectivity of these three analyses will be observed, and a wide range of applicable results for the overall structural response will be presented.

Research studies [1] have shown that PA results are always presented by a capacity curve, i.e., a curve that shows the ratio between the base shear and top displacement. The purpose of this method is to define the performance levels [2,3] for specific structures. These levels represent physical damage to structures owing to seismic loading. The results confirmed the accurate definition of performance levels based on the overall structural response.

THA $[1,4,5]$ is based on change in the displacement and base shear over time. The applicability of this method is influenced by the complexity of the selection of earthquake records. A THA set of earthquake records can be defined according to the different hazard demands and applicability. If the analysis must be done according to European seismic regulations, then a set of earthquake records must be defined in such a way that their spectrum is compatible with the Eurocode 8 [6] spectrum.

According to $[7,8]$, IDA helps us to define multiple incremental dynamic analysis curves that represent different seismic responses of incrementally scaled earthquake records for the same structure. As a result, a cumulative fragility curve can be presented as a lognormal function. The great advantage of IDA is the possibility of fragility curve application to similar structural systems.

In this study, static and dynamic nonlinear seismic analyses of a non-seismic reinforced concrete structure are conducted in order to determine the qualitative and quantitative differences and interconnections between the different analysis types. The interconnectivity and comparability of the presented methods is the novelty of this paper.

\section{METHODS OF SEISMIC ANALYSIS}

More sophisticated methods for the prediction of seismic response require more detailed analyses and more time. In this section, the general principles of the selected methods are introduced. The analyses conducted in this paper can be divided in nonlinear static and nonlinear dynamic procedures. THA and IDA are conducted as nonlinear dynamic analyses, while for nonlinear static analysis, PA was utilized.

\subsection{Pushover analysis}

PA is a nonlinear static procedure for the calculation of seismic response [1, 4, 9-15]. This method [1] is based on monotonically increasing lateral forces while keeping the vertical loads constant until the failure of the structure. The result of this method is a pushover or capacity curve, which is a curve of the base shear vs. top displacement that represents the nonlinear force-deformation properties (Figure 1), which directly take into account the effects of nonlinear material responses.

The results of this method [9] help us to define a collapse load and capacity of the structure. The capacity curve represents the yielding progress of the structure and the formation of plastic hinges [4].

According to [10], this method presents a good evaluation of the ultimate seismic response of multi-degreeof-freedom (MDOF) structures. In addition, the advantage of this method is the base share-top displacement relationship, which enables the determination of stiffness, strength, and displacement ductility. Otherwise, deformations obtained by this method can be very inaccurate because of its sensitivity to the applied load pattern. 

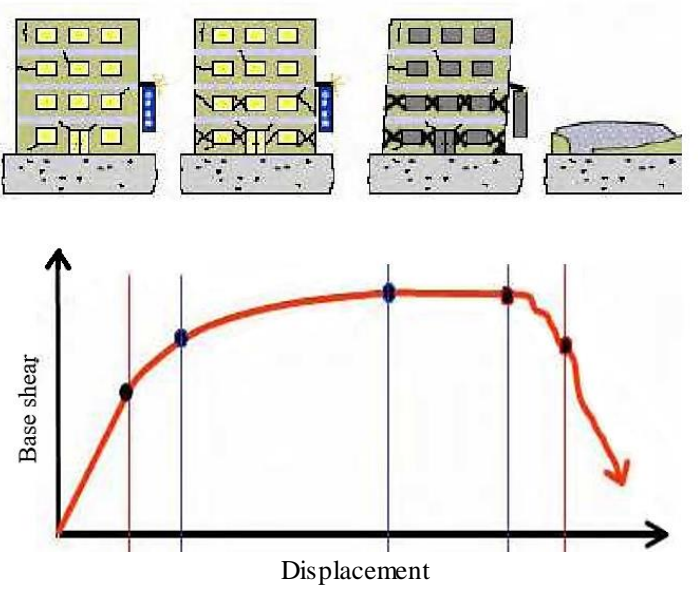

Figure 1 Example of pushover capacity curve [18]

PA is a much more applicable method in practice with respect to the needed computational time, particularly if the calculated structure is stiff and the first mode of response is dominant [13]. However, for irregular buildings where higher modes dominate, this method is not appropriate [1,10].

\subsection{Time history analysis}

THA is a nonlinear dynamic procedure for the calculation of nonlinear seismic responses [1, 4, 5, 16-19]. This is the most sophisticated and accurate method. The complexity and time required for calculation grows with accuracy. This is one of the reasons why the nonlinear dynamic procedure is still not frequently applied in practice.

According to [1], this analysis serves to predict the forces and displacements for every story of a building under seismic input that changes over time. The structural response can be highly influenced by a chosen ground motion, which is used as seismic input. For processing an effective time history analysis, several ground motion records are needed, preferably from real earthquake records (Figure 2). According to Eurocode 8 [6], utilizing real earthquake records is allowed if the mean value of the response spectrum for the chosen set of earthquakes does not underestimate the Eurocode 8 spectrum. The allowed tolerance is $10 \%$ in the range of the natural period of the structure. It is necessary that the mean response spectrum is created from at least seven seismic records [20].

In this method, the transversal and longitudinal directions of the structure can be analyzed at the same time. Still, the largest flaw of this method is its long computational time, which directly reduces its application in practice.

The earthquake record is described by an accelerogram [4] and defined by the peak ground acceleration (PGA), magnitude (M), and distance from the epicenter of the earthquake (R). The results from THA are based on the displacements and base shear in relation to time with a possible presentation of interstory dritt ratios (IDRs) and hysteretic curves.

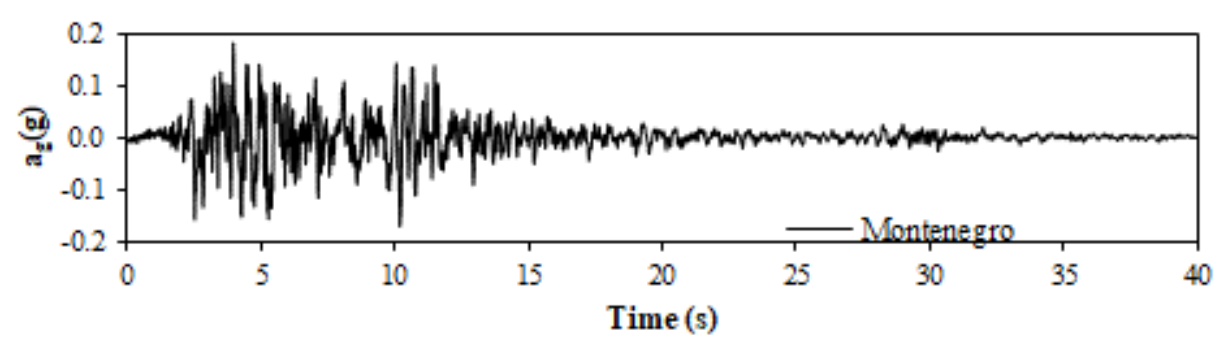

Figure 2 Accelerogram of Montenegro Ulcinj (1979)

\subsection{Incremental dynamic analysis}

IDA is a method for predicting seismic behavior under incrementally scaled ground motions [7-9, 21] as presented in Figure 3. This procedure efficiently estimates the responses of the model: elastic, yielding, nonlinear elastic, and global dynamic instability [9]. This analysis is represented by a relation between the Intensity Measure (IM) and

Karakaš, N, Kalman Šipoš, T, Hadzima-Nyarko, M 
Engineering Demand Parameter (EDP) for the structure. A suitable IM for moderate period structures is a 5\%damped first-mode Spectral Acceleration $\mathrm{Sa}\left(\mathrm{T}_{1}, 5 \%\right)$. The EDP is the response of structure and is often presented by IDRs. Additionally, it is necessary to define the Damage Measure (DM) or damage levels that represent a certain response owing to seismic loading [22]. Defining the DM is conditioned by the structural system, and two or more DMs may be needed for an effective analysis. The IDA curve represents a plot of a DM vs. one or more IMs.

An IDA curve begins with a straight line in the elastic area where it is directly proportional in correlation to IMDM [8]. At a higher scaling factor, when the seismic loading is strong enough to cause nonlinear yielding of the structure, the line starts to curve. A single IDA curve represents the response of one structure to different intensities of the same earthquake. Multiple IDA curves can be shown on the same graph, and they represent the response of the same structure to different seismic actions. Differences in the response of the structure indicate the importance of applying multiple IDAs (Figure 4a). Multiple IDAs can also be parametric (Figure 4b) when the parameters of the model change for the same seismic loading.

According to [21], when using the Peak Ground Acceleration (PGA) as an intensity measure, the elastic stiffness (ratio of IM to DM in the linear elastic area of the response) varies from record to record. However, if Sa $\left(T_{1}, 5 \%\right)$ is used as an intensity measure instead, the same result for the elastic stiffness is obtained. Consequently, to investigate the linear elastic area of the curves, $\mathrm{Sa}\left(\mathrm{T}_{1}, 5 \%\right)$ may be a more appropriate solution than PGA. This is because the sensibility of the dominant first-mode structures to the earthquake frequency is close to their firstmode frequency.

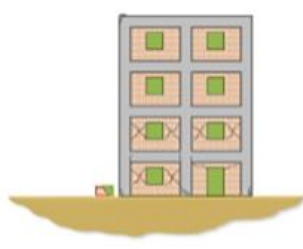

1

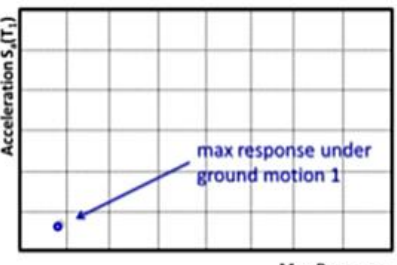

Max Response

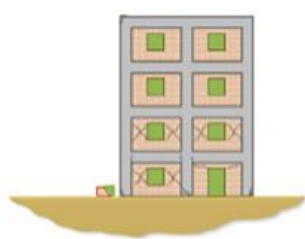

2

3

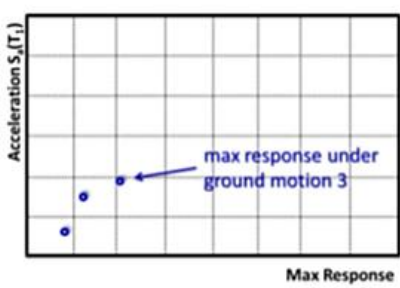

Max Response

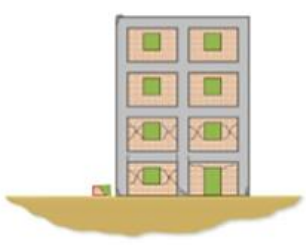

1

2 simhnum

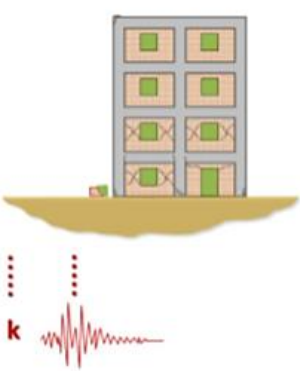

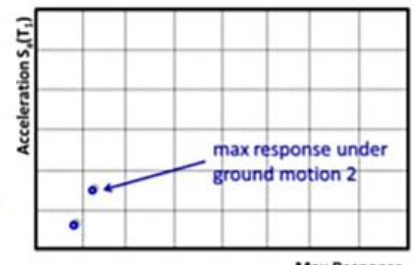

Max Response

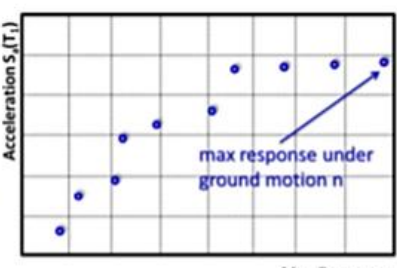

Max Response

Figure 3 Steps of incremental dynamic analysis using ground motion scaling [15]

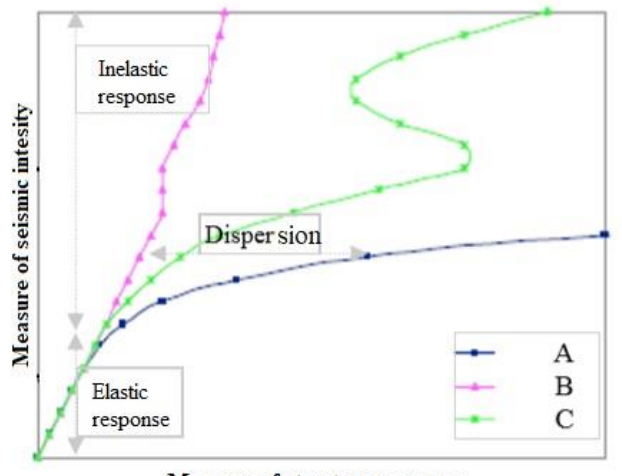

a)

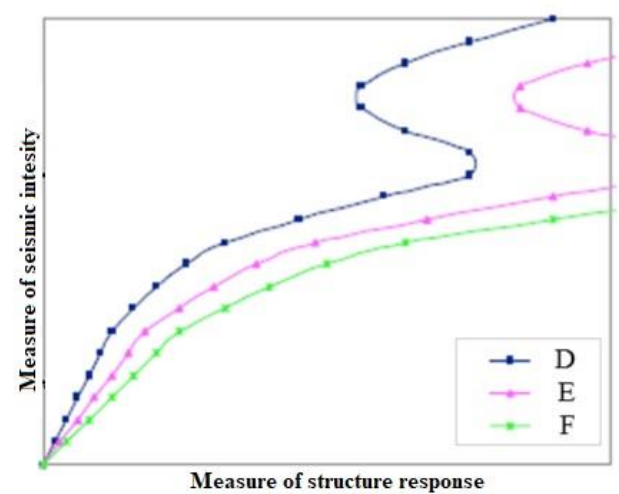

b)

Figure 4 Multiple IDAs: a) seismic, b) parametric [8] 


\section{CASE STUDY FOR APPLICATION OF DIFFERENT SEISMIC ANALYSES}

\subsection{Experimental model of ICONS frame}

The ICONS model (Figure 5) is a reinforced concrete (RC) four-story frame representing a non-seismic designed structure that is designed by taking into account the vertical loading without the applications of seismic regulations, as was the practice in structural construction until approximately 40 years in most countries in Europe [23]. The ICONS model was designed at the National Laboratory of Civil Engineering (LNEC) in Lisbon, Portugal, and then constructed in full scale and tested on a moderate earthquake at the European Laboratory for Structural Assessment (ELSA) in Ispra, Italy, in order to assess the seismic vulnerability of the frame.
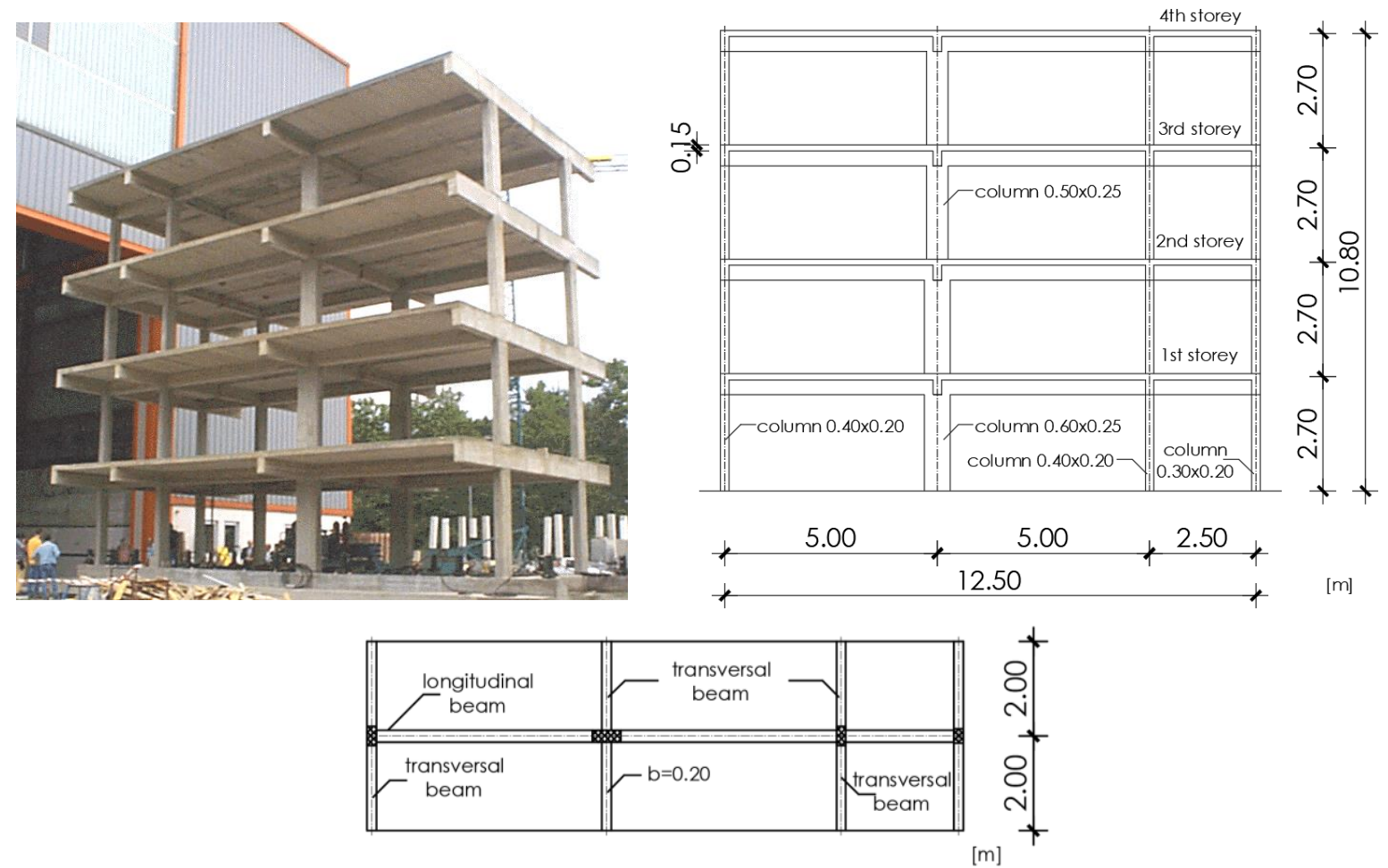

Figure 5 Model of structure ICONS [23]

\subsubsection{Material properties}

The experimental model is made of low-strength concrete C16/20 according to Eurocode 2 and smooth reinforcement Fe B22k classified according to Italian standards (Table 1).

Table 1 Values of concrete and steel reinforcement properties [23]

\begin{tabular}{lllc}
\hline \multicolumn{2}{l}{ Concrete properties } & \multicolumn{3}{l}{ Steel properties } \\
\hline $\mathrm{f}_{\mathrm{c}}(\mathrm{MPa})$ & 16.3 & $\mathrm{f}_{\mathrm{y}}(\mathrm{MPa})$ & 343 \\
$\mathrm{f}_{\mathrm{t}}(\mathrm{MPa})$ & 1.9 & $\mathrm{E}(\mathrm{MPa})$ & 200000 \\
$\mathrm{E}(\mathrm{MPa})$ & 18975.43 & $\varepsilon$ & 0.0024 \\
$\varepsilon$ & 0.002 & & \\
\hline
\end{tabular}

\subsubsection{Geometrical properties}

The model of the structure is $10.80 \mathrm{~m}$ in height and $12.50 \mathrm{~m}$ in width. It is a four-story frame with three bays. The first and second bays are $5 \mathrm{~m}$, while the last one is $2.50 \mathrm{~m}$. The height of each story is $2.70 \mathrm{~m}$ with a slab thickness of $0.15 \mathrm{~m}$. All columns and beams are dimensionally constant across the height of the structure with the dimensions presented in Figure 5. The dimensions of the beams are $0.25 \mathrm{~m} \times 0.50 \mathrm{~m}$ in the direction of loading, while the transversal beams are $0.20 \mathrm{~m} \times 0.50 \mathrm{~m}$. Details about the reinforcement arrangement and sizes of columns and beams can be found in [23].

Karakaš, N, Kalman Šipoš, T, Hadzima-Nyarko, M 


\subsubsection{Vertical and earthquake loading}

The vertical loads were defined to simulate dead loads except for the self-weight of the frame [23].

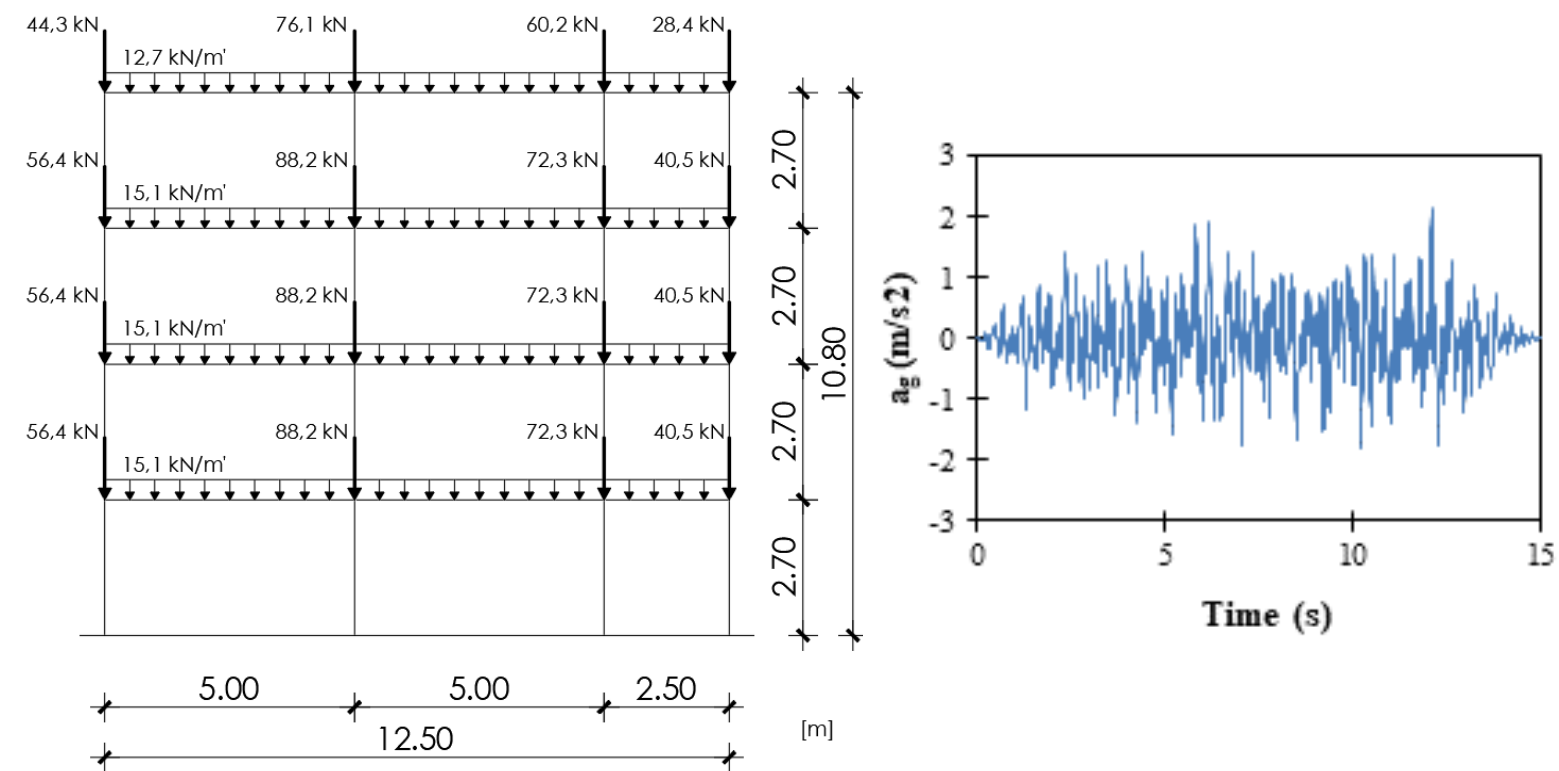

Figure 6 Vertical load and earthquake record used in structure [23]

Vertically distributed loads on the beams and concentrated loads on column nodes (Figure 6) represent the following loads: weights of slabs, finishings, and transverse beams and a live load of $1.0 \mathrm{kN} / \mathrm{m}^{2}$.

The selected earthquake record is a moderate-strong scenario of the European Seismic Hazard. Earthquake loading consists of a peak ground acceleration of $0.22 \mathrm{~g}$, i.e., $2.180 \mathrm{~m} / \mathrm{s}^{2}$, with a duration of $15 \mathrm{~s}$ for a return period of 475 years.

\subsubsection{General results of ICONS experimental model}

In order to make a realistic comparison with further analyses, the interstory drit ratio, and shear profiles, the results from experimental tests are presented in Figure 7.

BARE FRAME (BF)

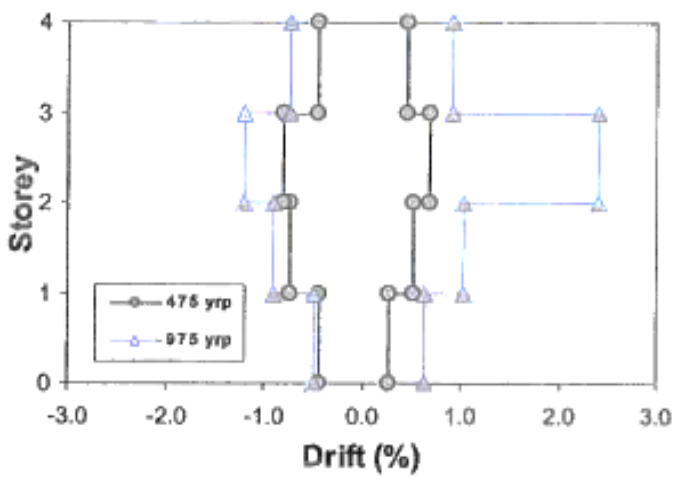

BARE FRAME (BF)

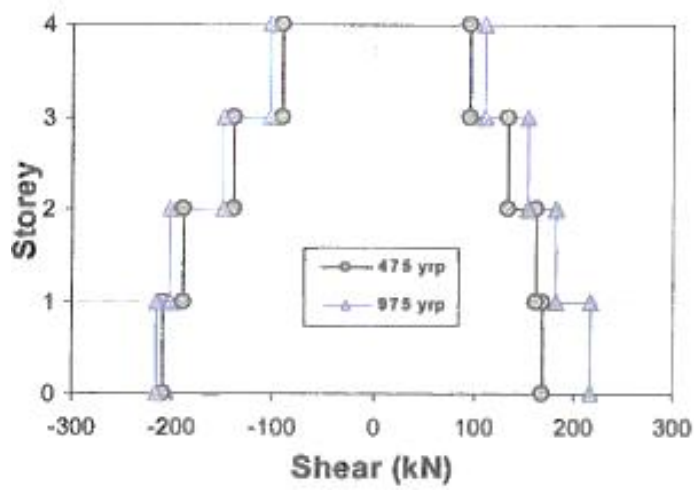

Figure 7 Maximum IDR and story shear profiles for BF475 (0.22 g) and BF975 $(0.29 \mathrm{~g})$ tests [23]

\subsection{Numerical model of ICONS frame}

A numerical model of the ICONS frame is constructed in SeismoStruct 2018 software [24]. The reinforced concrete elements were modeled as force-based (FBPH) elements with plastic hinges at the ends of the elements. For

Karakaš, N, Kalman Šipoš, T, Hadzima-Nyarko, M 
material nonlinearity, Mander's model of concrete [25] and the Menegotto-Pinto model (1973) for reinforcing steel [26] were used. The results are presented in Figure 8 and Tables 2 and 3.

Comparing the basic dynamic parameters of the experiment and the numerical model after the modal analysis, an excellent correlation was obtained when referring to the natural periods of the structure (Table 2).

Table 2 Comparison of natural periods of structure

\begin{tabular}{cccc}
\hline Mode & Experiment & Numerical model & Error (\%) \\
\hline 1 & 0.680 & 0.672 & 1.2 \\
2 & 0.231 & 0.226 & 2.2 \\
3 & 0.142 & 0.135 & 5.0 \\
\hline
\end{tabular}
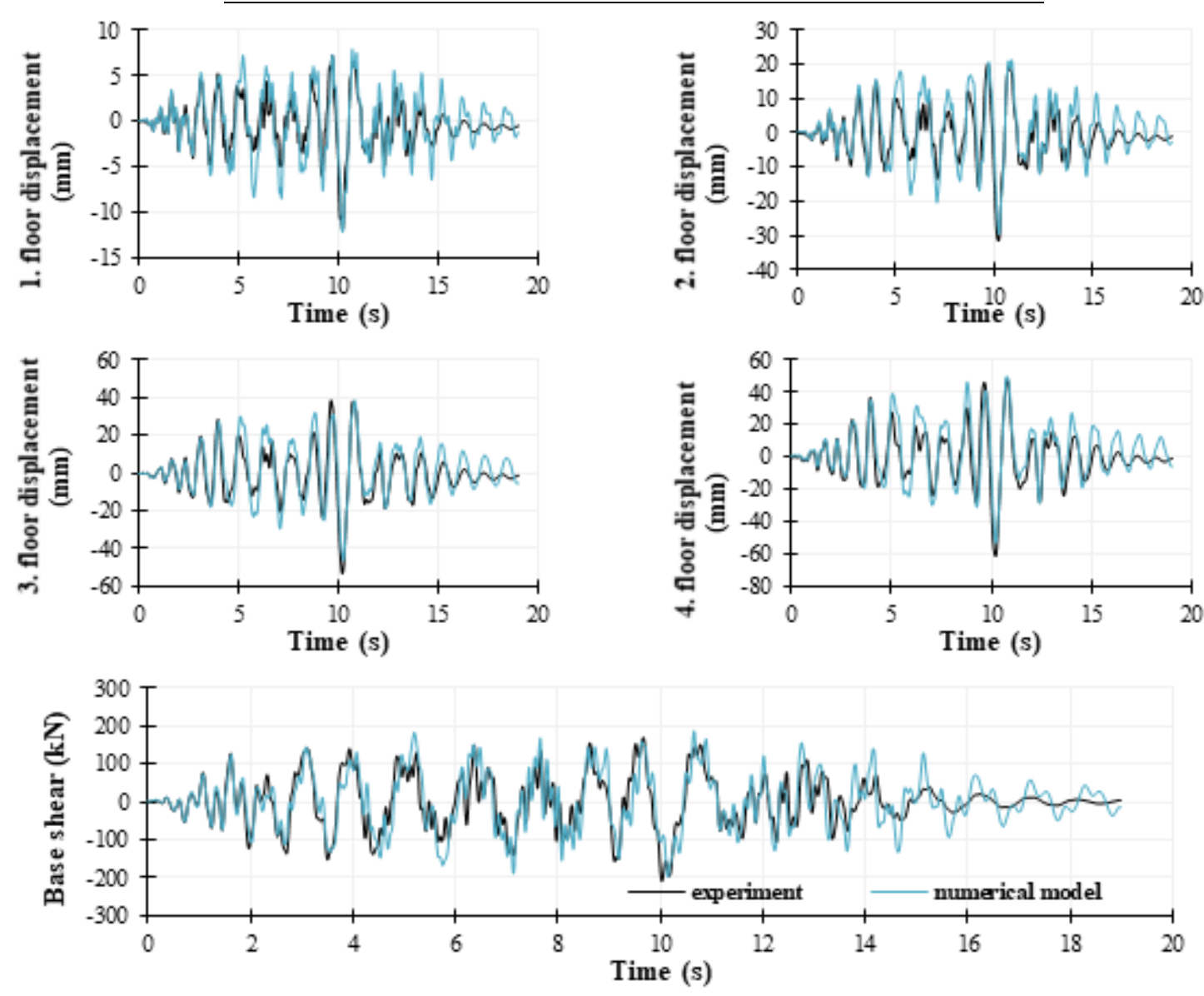

Figure 8 Results of ICONS numerical model: displacements of all floors and base shear

The average relative errors (values in braces in Table 3) were in the range of $1-18 \%$. The mean relative errors for the displacements and base shear were $6 \%$ and $14 \%$, respectively. The correlation between the curves given by the numerical modeling and experimental tests showed an excellent correlation with an average correlation coefficient of 0.88 .

Table 3 Compatibility of numerical ICONS model

\begin{tabular}{llccccc}
\hline & & $\begin{array}{l}\text { 1. displ. } \\
(\mathbf{m m})\end{array}$ & $\begin{array}{l}\text { 2. displ. } \\
(\mathbf{m m})\end{array}$ & $\begin{array}{l}\text { 3. displ. } \\
(\mathbf{m m})\end{array}$ & $\begin{array}{l}\text { 4. displ. } \\
(\mathbf{m m})\end{array}$ & $\begin{array}{l}\text { Base shear } \\
(\mathbf{k N})\end{array}$ \\
\hline Experiment & Min & -11.9 & -31.29 & -52.74 & -60.79 & -245.17 \\
& $\operatorname{Max}$ & 7.22 & 20.26 & 38.70 & 48.22 & 207.54 \\
\hline Numerical & $\operatorname{Min}$ & $-12.22\{3\}$ & $-29.85\{5\}$ & $-46.20\{12\}$ & $-53.97\{11\}$ & $-199.42\{18\}$ \\
model & $\operatorname{Max}$ & $7.82\{8\}$ & $21.12\{4\}$ & $38.94\{1\}$ & $48.96\{2\}$ & $185.59\{11\}$ \\
\hline Correlation & & 0.859 & 0.884 & 0.898 & 0.900 & 0.866 \\
\hline
\end{tabular}

Karakaš, N, Kalman Šipoš, T, Hadzima-Nyarko, M 


\subsection{Pushover analysis of ICONS frame}

PA in most cases is an overestimated method; however, it is very efficient in defining the performance levels for a specific building or a model of a certain construction type. Possible performance levels are as follows: slight damage $=$ immediate occupancy, moderate damage $=$ damage control, extensive damage $=$ life safety, and near collapse = collapse prevention according to HAZUS [2]. These levels indicate the physical damage to buildings that may occur during an earthquake event. A description of the damage at every structural performance level is needed to understand the physical state of the building for the end users in terms of the IDR (Table 4).

Table 4 Comparison of IDR (\%) according to structural performance levels and structure type [3]

\begin{tabular}{ccccc}
\hline & $\begin{array}{c}\text { Structural } \\
\text { performance level }\end{array}$ & infilled frames & RC walls & RC frames \\
\hline & Slight damage & $<0.10$ & $<0.20$ & $<0.20$ \\
N & Moderate damage & $<0.40$ & $<0.80$ & $<1.0$ \\
& Extensive damage & $>0.40$ & $>0.80$ & $>1.0$ \\
\hline & Near collapse & $>0.80$ & $>2.5$ & $>3$ \\
\hline
\end{tabular}

In order to evaluate the proposed values of IDR ratios for reinforced concrete (RC) frames, PA was performed on the ICONS frame by a triangular load pattern. A comparison with an experimental model (Figure 7) with results from a pushover analysis was confirmed by the value of the maximum shear and the capacity of the structure (210 $\mathrm{kN})$. Results from the numerical model were compared with a trilinear approximation based on the equal energy rule (Figure 9) and showed complete accuracy of the proposed values with the estimated ones. Therefore, these values will be used to evaluate the behavior of the bare RC frame according to THA and IDA.

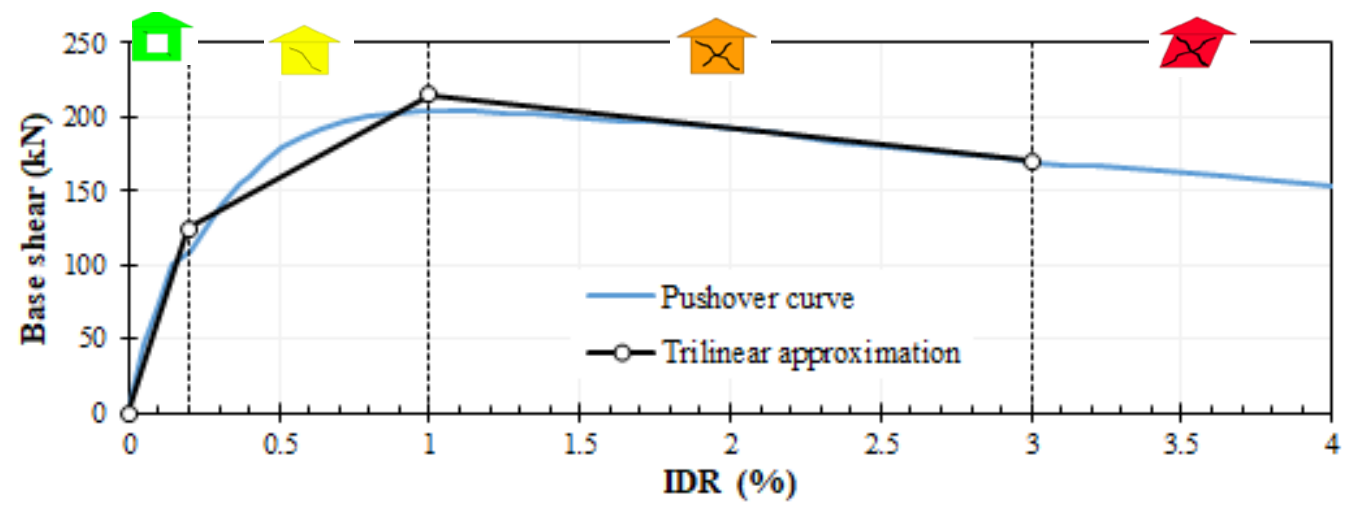

Figure 9 Capacity curve of ICONS model

\subsection{Time history analysis}

For THA, it is necessary to define earthquake records that will be used for numerical model calculations. Seven earthquake records are selected from seismic record databases [27-28] according to the recommendations from Eurocode $8[6]$ and the defined values of PGA.

Three ranges of values for three possible seismic areas were investigated. Peak ground accelerations of 0.1 $\mathrm{g}, 0.2 \mathrm{~g}$, and $0.3 \mathrm{~g}$ were analyzed in the THA and IDA. The chosen sets of earthquake records (Figure 10) are from [27] and are defined in the software REXEL [29]. This software gave us earthquake record sets with spectra that are compatible with Eurocode 8 spectrum type 1 (M 5.5) for soil type $C$ with the lowest possible deviation. 

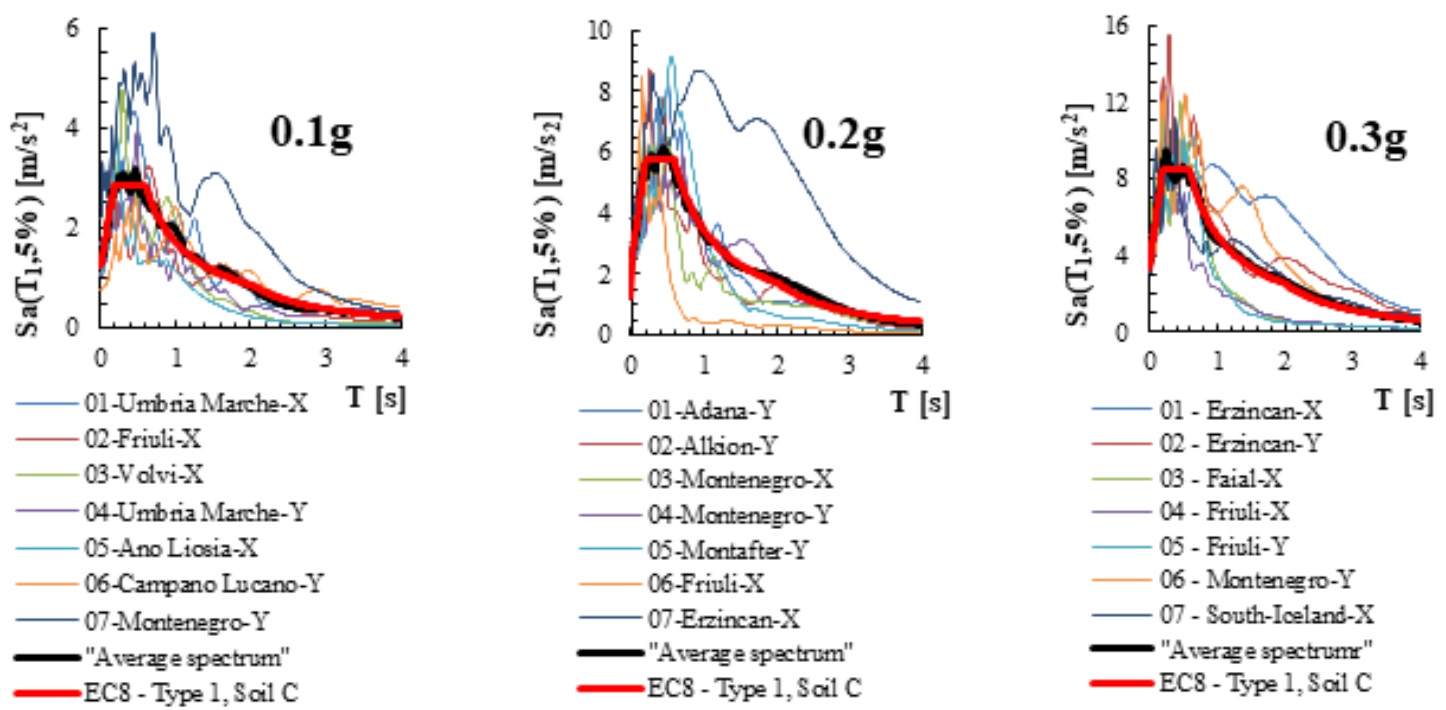

Figure 10 Selected sets for time history analysis

The results of THA are presented in order to define the performance levels for the investigated building under certain load levels. In Figure 11, displacements and interstory drift ratios are presented for every story and every load step with a mean line for every corresponding parameter. A comparison with an experimental model (Figure 7) with results from a time history analysis (Figure 12) is confirmed by the values of the ID ratios.
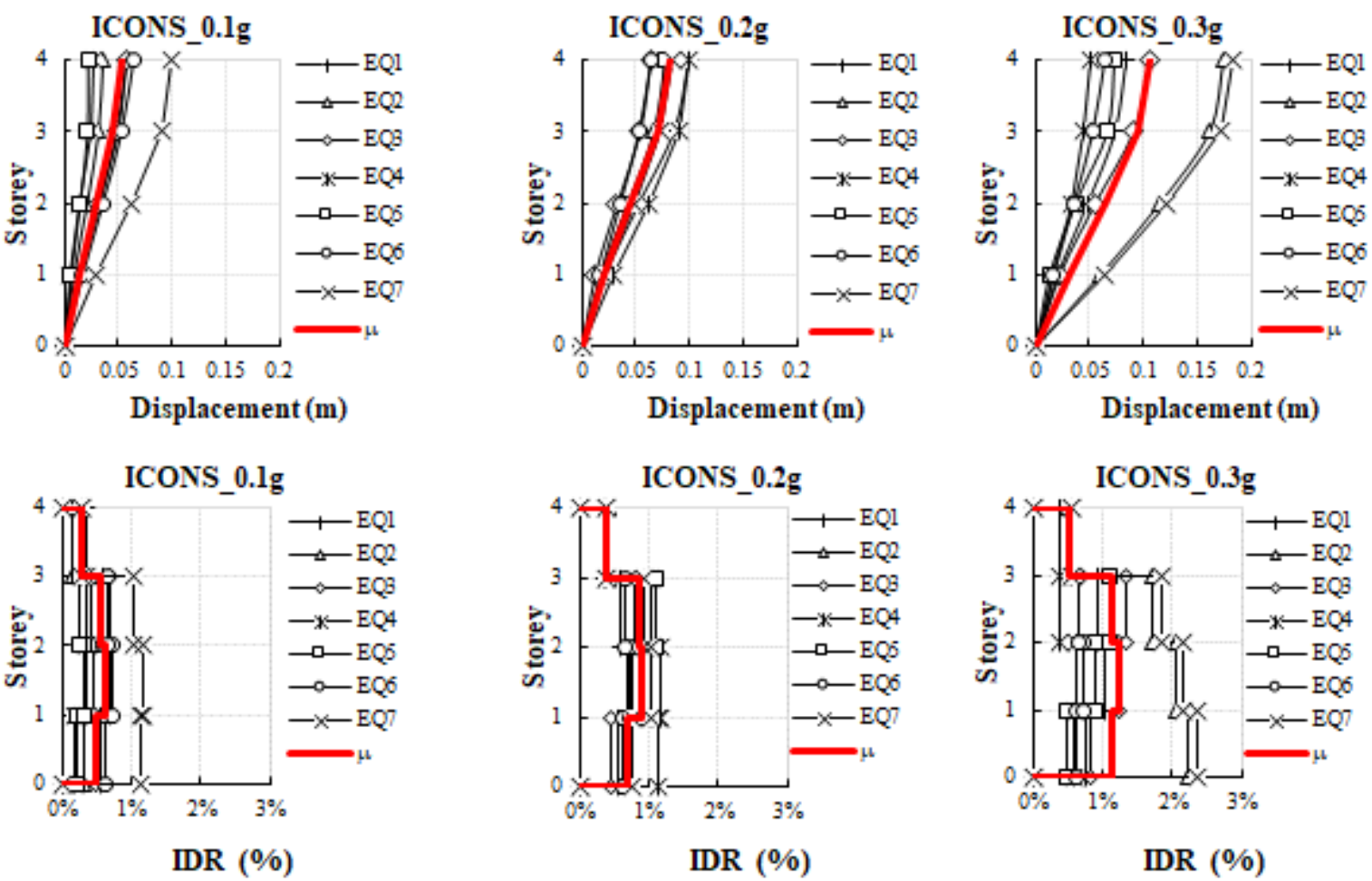

Figure 11 Displacements and interstory drift ratios (IDRs) for ICONS building and different load levels

In order to make an easier comparison between IDR and load levels, their relation is presented in Figure 11. The displacement and IDR profiles change almost in a linear manner. The relationship between the maximum IDR and PGA is purely linear for the analyzed range of peak ground acceleration values [the range from $0.1 \mathrm{~g}$ to $0.3 \mathrm{~g}$ can be represented by a linear equation IDR $(\%)=0.0308$ PGA +0.0032 , where PGA is in g]. However, in order to obtain a curve that can predict the performance for values lower than $0.1 \mathrm{~g}$ of PGA, an additional range is defined 
based on the assumption that if there is no earthquake, there is no damage. A fourth dot is added to the origin of the presented graph (Figure 12c).

ICONS

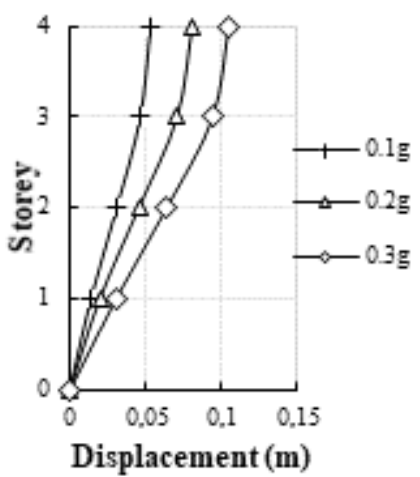

ICONS

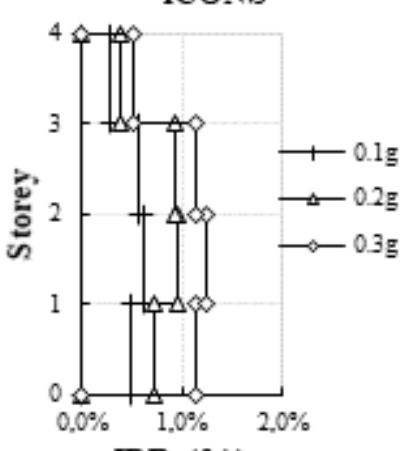

IDR (\%)

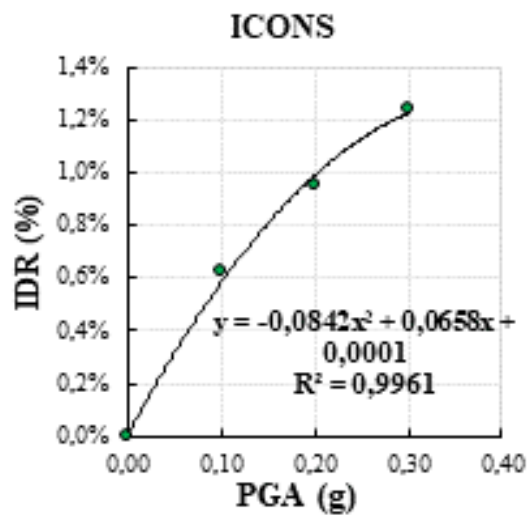

Figure 12 (a) Mean displacements and (b) interstory drift ratios (IDRs) for ICONS building. c) Relationship between IDR and PGA based on results of analysis

The relation between PGA and IDR is a polynomial with the presented equation for the evaluation of possible damage.

\subsection{Incremental dynamic analysis}

By determining the damage states and by conducting an incremental dynamic analysis on nonlinear numerical models, results were shown with IDA curves and fragility curves, and were finally expressed with a discrete probability of exceeding a certain limit state.

The IDA curve was determined by varying the relative interstory dritt ratio depending on the incremental change in spectral acceleration $\left(T_{1}, 5 \%\right)$ for the set of seven earthquake records. Cumulative fragility curves were shown as a lognormal function for each limit state as a mean response of the earthquakes from the IDA curves. To establish the probability of the structural damage level, it is important to determine the first natural period of the structure and its corresponding spectral acceleration of the medium response spectrum. Figure 13 presents results from an incremental dynamic analysis according to the level of damage. As expected, these results indicate a trend of increasing damage in the direction of a higher seismic load. An advantage of IDA is the applicability of fragility curves for similar structural systems based on the first natural period and corresponding spectral acceleration. 

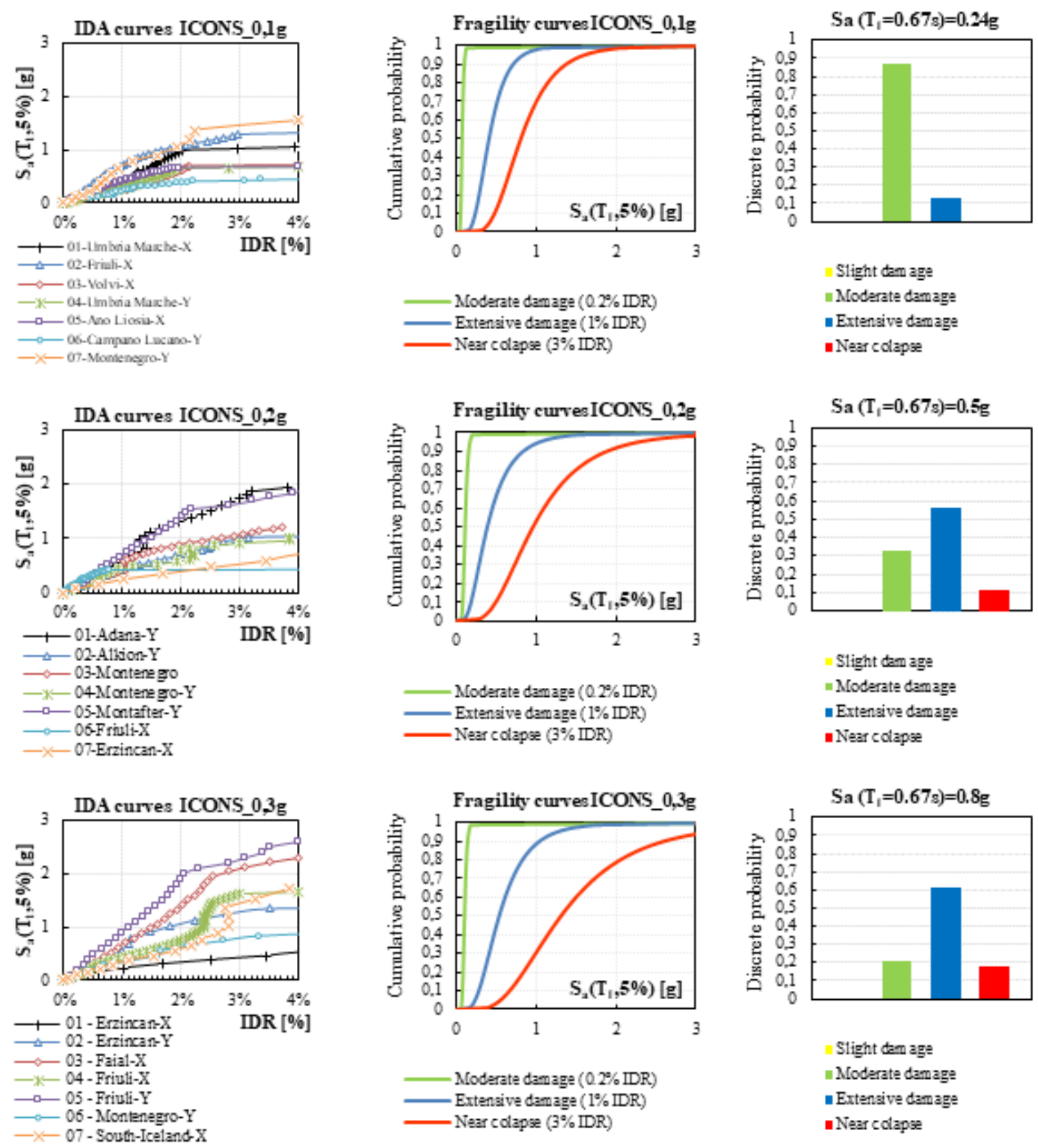

Figure 13 IDA curves, fragility curves, and expected performance levels of ICONS building

\section{CONCLUSION}

In the present study, the estimation of a bare RC non-seismic building was investigated through the application of different nonlinear numerical analyses. Particular attention was focused on the achieved performance levels based on the global structural response. An experimental model called ICONS was calibrated with a numerical nonlinear model that was able to present the accurate behavior of the RC frame building. A nonlinear pushover analysis, time history, and incremental dynamic analysis were performed and examined.

From the results obtained, it can be noted that the pushover analysis gave an accurate definition of the performance levels based on the overall structural response. The time history analysis results were based on the behavior of one structure with sets of earthquake records. The results gave an equation for the prediction of the 
interstory drift ratio based on the possible peak ground acceleration for similar structures. On the other hand, an incremental dynamic analysis can be much more useful for various bare RC structures where a certain performance level can be defined from presented fragility curves based on the first natural period of the structure. Finally, the best approach that can be used for the seismic and damage evaluation of structures is a combination of the presented analyses according to the wide range of applicable results for the overall structural response.

According to the results of analyses for seismic zones with peak ground accelerations of $0.2-0.3 \mathrm{~g}$, the appearance of damage can be noted. This corresponds to the performance level of extensive damage that is likely to be expected, as the structure is not reinforced in accordance with seismic regulations.

A more comprehensive parametric analysis of reinforced concrete structures that will evaluate the influence of the number of stories and types of reinforced concrete frames according to the reinforcement ratios can be helpful for an extended analysis in a wider range of possible conditions.

\section{References}

[1] Lang, K. 2002: Seismic vulnerability of existing buildings, Report, Institute of Structural Engineering Swiss Federal Institute of Technology, Zurich, https://doi.org/10.3929/ethz-a-004333389

[2] HAZUS MH-MR5. 2001: Earthquake loss estimation methodology, Technical Manual, https://www.fema.gov/hazus/, Accessed 1 October 2018.

[3] Ghobarah, A. 2004: On drit limits associated with different damage levels, International Workshop on Performance-Based Seismic Design, Department of Civil Engineering, McMaster University, Ontario, Canada

[4] Čada, P.; Máca, J. 2017: Comparison of methods used for seismic analysis of structures. Acta Polytechnika CTU Proceedings,13, pp. 20-27, https://doi.org/10.14311/APP.2017.13.0020

[5] Mitrović, S.; Čaušević, M. 2009: Nelinearni statički seizmički proračuni konstrukcija; Građevinar, 61, pp. 521-531.

[6] European Committee for Standardization; CEN: Eurocode 8: Design of structures for earthquake resistance, Part 1: General rules, seismic actions and rules for buildings, Brussels, EN 1998-1 (2004). 2004;1(2004).

[7] Vamvatsikos, D.; Fragiadakis, M. 2009: Incremental dynamic analysis for estimating seismic performance sensitivity and uncertainty, Earthquake Engineering and Structural Dynamics, 39(2), pp. 1-16 https://doi.org/10.1002/eqe.935

[8] Kalman Šipoš, T. 2013: Performance based seismic design of masonry infilled frames, PhD Thesis, Faculty of Civil Engineering Osijek, Osijek,

[9] D’Ayala, D.; Meslem, A.; Vamvatsikos, D.; Porter, K.; Rossetto, T.; Silva, V. 2015: Guidelines for analytical vulnerability assessment of Low/Mid -Rise Buildings, Vulnerability Global Component Project

[10] Hamzah, H.F.; Wee, T.; Liew, M.S. 2011: A review of seismic assessment of reinforced concrete structure using pushover analysis, 2011 National Postgraduate Conference, Kuala Lumpur, Malaysia

[11] Hanafiah; Saloma, H.; Yakni, I.; Yahya, J. 2017: The behaviour study of shear wall on concrete structure by pushover analysis, International Journal on Advanced Science Engineering and Information Technology, 7(4), pp. 1127-1133. http://dx.doi.org/10.18517/ijaseit.7.4.2495

[12] Hemmati, A.; Santini, A.; Moraci, N. 2008: Static nonlinear analysis in concrete structures. AIP Conference Proceedings, 2008 Seismic engineering conference: Commemorating the 1908 Messina and Reggio Calabria earthquake; Reggio Calabria (Italy), pp. 1020:947-54, http://dx.doi.org/10.1063/1.2963936

[13] Martino, R.; Spacone, E.; Kingsley, G. 2000: Nonlinear pushover analysis of RC structures, Proceedings of Structures Congress 2000, Advanced technology in structural engineering, Philadelphia, Pennsylvania, pp.1-8. http://dx.doi.org/ 10.1061/40492(2000)38

[14] Attari, N.E.; Chemrouk, M.; Amziane, S. 2013: Pushover analysis of a seismic strengthening of an existing building reinforced concrete structure. Advanced Material Research, 641-642, pp. 583-590, https://doi.org/10.4028/www.scientific. net/AMR.641-642.583

[15] Chopra, A.K.; Goel, R.K. 2004: A modal pushover analysis procedure to estimate seismic demands for unsymmetric-plan buildings. Earthquake Engineering and Structural Dynamics. 33(8), pp.903-927, https://doi.org/10.1002/eqe.380

[16] Affidddin, M.; Panjaitan, M.A.R.; Ayuna, D. 2017: The behaviour of reinforced concrete structure due to 
earthquake load using time history analysis method. IOP Conference Series: Earth and Environmental Science; 56, pp.1-8. https://doi.org/10.1088/1755-1315/56/1/012013

[17] Belostotskiy, A.M.; Akimov, P.A.; Dmitriev, D.S. 2018: About contemporary seismic analysis of underground structures. Materials Science Forum, 931, pp.91-99, https://doi.org/10.4028/www.scientific.net/MSF.931.91

[18] Mohi-Ud-Din, F.; Pavithra, C. 2017: Seismic analysis of core structure. International Journal of Engineering Trends and Technology, 47(5), pp. 275-86, https://doi.org/10.14445/22315381//JETT-V47P245

[19] lervolino, I.; Cornell, C.A. 2005: Record selection for nonlinear seismic analysis of structures. Earthquake Spectra. 21(3), pp. 685-713. https://doi.org/10.1193/1.1990199

[20] lervolino, I.; Maddaloni, G.; Cosenza, E. 2008: Eurocode 8 compliant real record sets for seismic analysis of structures. Journal of Earthquake Engineering; 12 (1), pp. 54-90, https://doi.org/10.1080/13632460701457173

[21] Tran, T.; Nguyen, T.; Park, J.; Kim, D. 2017: Nonlinear behaviour of reinforced concrete structures using incremental dynamic analysis considering height effects, The 8th Asia and Pacific Young Researchers and Graduates Symposium, Japan (YRGS 2017), pp.1-6.

[22] Vamvatsikos, D.; Cornell, C.A. 2002: Incremental dynamic analysis. Earthquake Engineering and Structural Dynamics, 31(3), pp. 491-514, https://doi.org/10.1002/ege.141

[23] Pinto, A.; Verzeletti, G.; Molina, J.; Varum, H.; Pinho, R.; Coelho, E. 2002: Pseudo-dynamic tests on nonseismic resisting RC frames (bare and selective retrofit frames), EUR 20244EN, Report, Joint Research Centre, Ispra.

[24] Seismosoft (2018) SeismoStruct: A computer program for static and dynamic nonlinear analysis of framed structures, http://www.seismosoft.com. Accessed 1 October 2018.

[25] Mander, J.B.; Priestley, M.J.N.; Park, R. 1988: Theoretical stress-strain model for confined concrete. ASCE Journal of Structural Engineering, 114(8), pp. 1804-1826.

[26] Menegotto, M.; Pinto, P.E. 1973: Method of analysis for cyclically loaded reinforced concrete plane frames including changes in geometry and non-elastic behavior of elements under combined normal force and bending. Proceedings, IABSE Symposium on Resistance and Ultimate Deformability of Structures Acted on by Well Defined Repeated Loads, Lisbon; pp. 15-22.

[27] Ambraseys, N.; Smit, P.; Sigbjornsson, R.; Suhadolc, P.; Margaris, B. 2002: Internet-site for European strong-motion data, European Commission, Research Directorate General, Environment and Climate Programme.

[28] Ancheta, T.D.; Darragh, R.B; Stewart, J.P.; Seyhan, E.; Silva, W.J.; Chiou, B.S.J.; Wooddell, K.E.; Graves, R.W.; Kottke, A.R.; Boore, D.M.; Kishida, T.; Donahue, J.L. 2013: PEER 2013/03: PEER NGA-West2 Database. http://peer.berkeley.edu/products/strong_ground_motion_db.html Accessed 1 October 2018.

[29] lervolino I., Galasso C., Cosenza E. 2009: REXEL: computer aided record selection for code-based seismic structural analysis. Bulletin of Earthquake Engineering, 8, pp. 339-362. https://doi.org/10.1007/s10518-009$\underline{9146-1}$

Please cite this article as:

Karakaš, N.; Kalman Šipoš, T.; Hadzima-Nyarko, M.: Application of different seismic analyses to RC structures, Electronic Journal of the Faculty of Civil Engineering Osijek-e-GFOS, 2018, 17, pp. 38-51, htps://doi.org/10.13167/2018.17.5 